http://ejournal.upi.edu/index.php/jaz - e-mail: jurnal_zonasi@upi.edu doi.org/10.17509/jaz.v4i2.28087

\title{
PERANCANGAN KAWASAN WISATA DESA BOKOR DENGAN PENDEKATAN ARSITEKTUR TEPIAN AIR
}

Article History:
First draft received:
7 September 2020
Revised:
25 April 2021
Accepted:
10 Juni 2021
First online:
10 Juni 2021
Final proof received:
Print:
15 Juni 2021
Online
15 Juni 2021
Jurnal Arsitektur ZONASI
is indexed and listed in
several databases:
SINTA 4 (Arjuna)
GARUDA (Garda Rujkan Digital)
Google Scholar
Dimensions
oneSearch
BASE
Member:
Crossref
RJI
APTARI
FJA (Forum Jurna Arsitektur)
IAI
AJPKM

\section{Pahmi Iria ${ }^{1}$}

Wahyu Hidayat ${ }^{2}$

Yohannes Firzal $^{3}$

1,2,3 Universitas Riau, Pekanbaru, Indonesia

Kampus Bina Widya, Jl. HR. Soebrantas KM 12.5, Simpang Baru, Tampan, Kota Pekanbaru, Riau

Email: pahmi.iria2300@student.unri.ac.id wahyu.hidayat@lecturer.unri.ac.id yfirzal@eng.unri.ac.id

Abstract: Bokor Village is not only from the natural side, but also culture, arts, crafts, culinary, and historical relics. Bokor Village also as a tourist gate is still very minimal with the facilities provided by the Government and local people, this is caused by a lack of socialization about tourism in Bokor village. So, the tourism area of the Bokor village to make it easier for tourists to enjoy the tourism in Bokor village, especially on the banks of the Bokor River, then be treated to design waterfront architecture approach in this area. So in this design apply the concept of tual Sago in the region. The activities in the area are oriented towards the water, and are able to help the activities in the area.

Keywords: Bokor Village, tourism area, Waterfront Architecture.

\begin{abstract}
Abstrak: Desa Bokor selain memiliki sisi alam yang mempesona, Desa Bokor juga memiliki budaya, kesenian, kerajinan, kuliner daerah, hingga peninggalan bersejarah yang terpendam. Desa Bokor juga sebagai gerbang wisata masih sangat minim dengan fasilitas yang disediakan oleh pemerintah dan masyarakat setempat, ini diakibatkan oleh kurangnya sosialisasi tentang pariwisata pada Desa Bokor. Maka diperlukanlah perancangan kawasan wisata Desa Bokor untuk memudahkan wisatawan menikmati wisata yang ada di Desa Bokor khususnya di tepian sungai bokor maka diterapkanlah perancangan pendekatan arsitektur tepian air pada kawasan ini. Sehingga pada perancangan ini menerapkan konsep tual sagu pada kawasan. Maka aktifitas pada kawasan nantiknya berorientasi kearah air, dan mampu membantu setiap kegiatan yang ada pada kawasan.
\end{abstract}

Kata Kunci: Desa Bokor, Kawasan Wisata, Arsitektur Tepian Air.

\section{Pendahuluan}

Desa Bokor juga menjadi tempat diselenggarakannya sebuah event besar di Provinsi Riau yang berskala tingkat internasional. Dengan adanya festival ini, Desa Bokor menawarkan pertunjukan dari berbagai pentas kesenian seperti musik tradisional daerah, musik moderen, ghazal, dan tari ayak sagu. Kegiatan lain yang ada pada acara festival ini adalah menelusuri hulu sungai bokor dan kuliner makanan. Selain acara diatas ada juga beberapa acara yang terselenggara setiap tahunnya di Desa Bokor ini yakni Festival bokor reviera, Festival bokor folklore, Pesta sungai bokor, Bokor one night, Bokor river internasiaonal reggae festival, Bokor world music festival dan lain sebagainya (Pemdes Desa Bokor, 2019).

Desa Bokor juga sebagai gerbang wisata yang ada di Kabupaten Kepulauan Meranti, mengembangkan pariwisata yang berbasis desa wisata masyarakat, kesehatan, meningkatkan infrastruktur ekonomi, pendidikan dalam rangka mensejahterakan masyarakat dan dengan pembinaan mental spiritual, serta menjadikan kepariwisataan sebagai sasaran dan asset Kabupaten Kepulauan Meranti (Pemdes Desa Bokor, 2019). 
Sebagai tanggapan untuk menyediakan wadah yang dapat menunjang atau membantu berjalannya kegiatan baik dari segi pariwisata mau pun kesenian yang ada dikawasan ini, maka dibutuhkan konsep Perancangan Kawasan Wisata Desa Bokor di Kabupaten Kepulauan Meranti.

Dalam hal seni pertunjukan lokal, maka kreatifitas tersebut harus mampu diwujudkan dalam bentuk yang menarik, atraktif dan mampu menyajikan pesan serta cerita dalam rentang waktu kunjungan yang terbatas. Pengembangan seni pertunjukan wisata perlu mendapat perhatian, khususnya pada destinasi dimana pengembangan kepariwisataan yang menekankan pada pariwisata seni (Hanggoro, 2012). Seni pertunjukan, sebagai bagian dari jaringan budaya dapat dibatasi untuk dikaitkan dalam modus apapun dengan struktur dari institusi-institusi dalam sebuah masyarakat. Lebih lanjut lagi, terdapat hubungan antara institusi yang memberikan arah dengan tumbuhnya kebutuhan dan tuntutan karya-karya atau kegiatan-kegiatan yang ada dalam seni pertunjukan (Sedyawati, 1998, 2).

Dari setiap kegiatan yang ada di Desa Bokor masih sangat minim dengan fasilitas yang disediakan oleh pemerintah dan masyarakat setempat. Ini diakibatkan oleh kurangnya sosialisasi tentang pariwisata pada Desa Bokor. Pada kegiatan menelusuri sungai bokor akses dermaga yang masih kurang memadai untuk digunakan oleh para wisatawasan dan juga masyarakat setempat. Kegiatan wisata mangrove juga masih memiliki akses setapak sehingga menyulitkan wisatawan untuk berkunjung. Sedangkan pada kegiatan kesenian masih banyak kekurangan yang dimiliki seperti panggung yang disediakan seadanya agar acara tetap berlangsung. Pada kegiatan kuliner para masyarakat harus menyediakan tempat sendiri sehingga pada kawasan tidak tertata dengan baik. Pada kegiatan kerajinan setempat seperti kerajinan ayaman dari pohon bambu yang dimana masyarakat hanya melakukan disetiap rumah, karena belum adanya wadah bagi pengrajin ayaman setempat. Homestay untuk wisatawan juga tidak tersedia di Desa Bokor sehingga wisatawan harus tinggal dirumah masyarakat setempat untuk beristirahat. Desa Bokor juga memiliki beberapa barang peninggalan bersejarah yang masih tersimpan dirumah rumah warga, ini dikarenakan tidak adanya wadah untuk menampung barang barang peninggalan tersebut (Pemdes Desa Bokor, 2019).

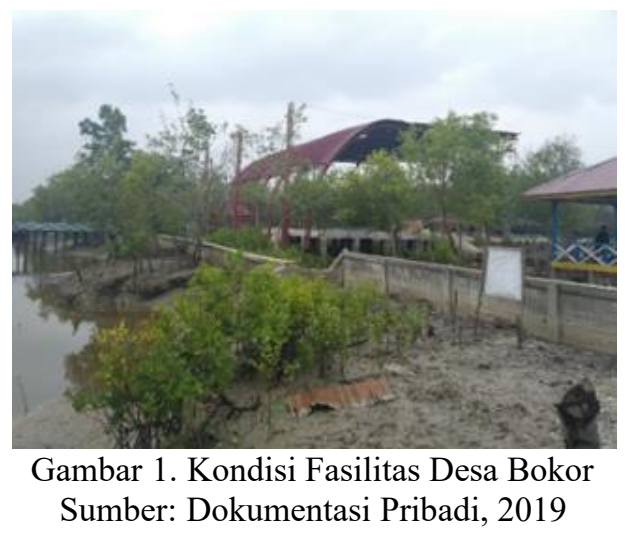

Pada Perancangan Kawasan Wisata Desa Bokor di Kabupaten Kepulauan Meranti memerlukan perencanaan pada waterfront dengan perancangan yang baik serta bisa memenuhi kebutuhan wisatawan maupun kesenian, oleh karena itu, maka diterapkanlah perancangan pendekatan arsitektur tepian air pada kawasan ini, yang bertujuan untuk membantu akses dari setiap kegiatan wisatawasan yang berkunjung. Selain itu potensi dari setiap kegiatan yang di adakan pada Desa Bokor lebih banyak beraktifitas di air, contohnya seperti festival lari di atas tual sagu, dan juga menelusuri sungai bokor dan hutan mangrove. Dengan pengembangan arsitektur tepian air maka aktifitas pada kawasan nantiknya berorientasi kearah air, sehingga penerapan pada tema juga terwujudkan dengan baik dan mampu membantu setiap kegiatan yang ada pada kawasan.

Adapun permasalahan yang akan dikaji pada Perancangan Kawasan Wisata Desa Bokor adalah bagaimana rumusan penataan kawasan wisata Desa Bokor sebagai fasilitas yang dapat mewadahi kegiatan wisatawan, bagaimana perumusan perancangan Kawasan Wisata Desa Bokor melalui prinsip-prinsip Arsitektur Tepian Air, dan bagaimana perumusan konsep kawasan yang tepat kedalam Kawasan Wisata Desa Bokor.

Desa Bokor memiliki hutan mangrove yang belum dimanfaatkan secara optimal. Salah satu upaya yang dapat dilakukan untuk mengoptimalisasi adalah dengan menjadikan kawasan ekowisata. Hutan Bakau bukan saja menjaga kelestarian bumi tetapi juga keindahan alam. Ekosistem mangrove mempunyai komponen sumber daya alam berupa bentang alam, flora, fauna dan masyarakat setempat saling berinteraksi menjadi 
kesatuan ekosistem yang memiliki fungsi ekologis, ekonomis, dan sosial penting dalam pembangunan di wilayah pesisir (Pemdes Bokor, 2019).

Wisata yang dikemukakan oleh para ahli, diantaranya menurut James J. Spillane dan Koen Meyers (Spillane, 1982), Wisata adalah kegiatan perjalanan dengan tujuan mendapatkan kenikmatan, menikmati olahraga atau istirahat, mengetahui sesuatu, mencari kepuasan, memperbaiki kesehatan, menunaikan tugas, berziarah dan lain-lain. Wisata adalah aktivitas perjalanan yang dilakukan oleh seseorang dengan waktu dari tempat tinggal semula ke daerah tujuan dengan alasan untuk memenuhi rasa ingin tahu, menghabiskan waktu senggang atau libur serta tujuan-tujuan lainnya (Meyers, 2009).

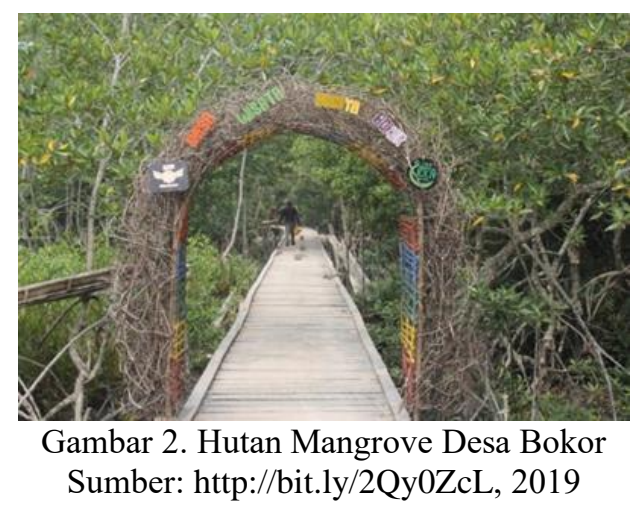

Kesenian yang ada di Desa Bokor merupakan kelompok pemuda pemudi yang awal bergerak dari sanggar seni budaya melayu, yang sudah berkiprah di belahan dunia. Sanggar Bathin Galang juga sudah sering mempromosikan Desa Bokor sebagai desa wisata budaya dan beberapa event musik yang sudah di selenggarakannya oleh Sopandi S.Sos Ketua dari kelompok sanggar (Pemdes Bokor, 2019).

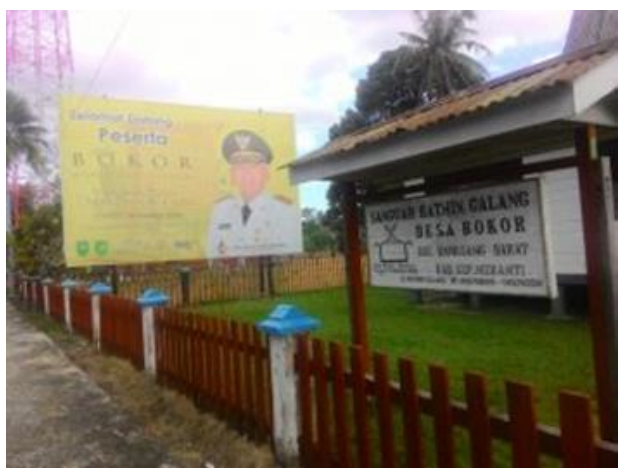

Gambar 3. Gedung Kesenian Bathin Galang Sumber: http://bit.ly/2Hlk7F9, 2019

Desa Bokor juga memiliki benda-benda peninggalan sejarah yang masih disimpan oleh masyarakat sekitar Desa Bokor. Peninggalan ini berupa kendi-kendi, piring-piring sejarah, surat, dan masih banyak lagi. Dan ini disimpan dan dirawat oleh masyarakat sekitar dirumah mereka, ini dikarenakan tidak adanya tempat penampungan atau wadah untuk benda-benda bersejarah yang ada di Desa Bokor.

Di Desa Bokor tepatnya di Tanah Kuning merupakan kelompok masyarakat bokor yang dimana mereka selalu memanfaatkan karyanya dalam pembuatan keranjang dari bahan pohon bambu. Hal ini bertujuan untuk mengenalkan Tanah Kuning adalah salah satu desa yang memproduksi bahan kerajinan lokal desa. Disana mereka sudah mempersiapkan beberapa model kerajinan yang telah di buat untuk dijual bagi tamu yang ingin membeli dan tamu yang ingin belajar. Hal ini biasa dilakukan dirumah-rumah warga desa yang menghasilkan kerajinan, karena belum adanya wadah untuk menampung kegiatan para pengrajin ini. 


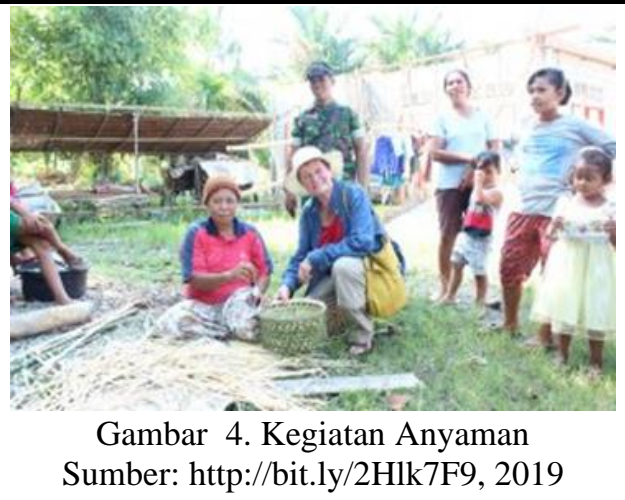

Desa Bokor juga menjadi tempat diselenggarakannya sebuah event besar di Riau yang berskala tinggat internasional. acara festival ini mengundang berbagai seniman dan sastrawan manca negara seperti Singapura, Malaysia, Thailand, Francis, Rumania, Wales, Inggris, Afrika Selatan, Korea dan sebagaian juga tamu dari dalam negeri. Dengan adanya agenda acara festival di Desa Bokor menawarkan pertunjukan dari berbagai pentas kesenian seperti musik tradisional dan musik moderen, musik ghazal, silat, dan juga tari ayak sagu. Kegiatan lain pada acara festival yang ada di Bokor ini adalah menelusuri hulu sungai bokor dengan menggunakan sampan dan menjadi sebuah pesta yang mewujukan mimpi besar sebagai salah satu kawasan wisata budaya Riau.

\section{Metode Penelitian}

Penelitian dilakuan di Jl. Bathin galang, Desa Bokor, Kecamatan Rangsang Barat, Kabupaten Kepulaun Meranti, Provinsi Riau dengan menggunakan metode pengumpulan data dengan pengumpulan data primer dan data sekunder. Pengumpulan data primer di laksanakan dengan cara survey lapangan, dokumentasi lapangan, dan wawancara. Data sekunder berasal dari kajian jurnal, buku, skripsi, tesis,disertasi, dan media dengan pengumpulann hasil data yang berhubungan dengan penerapan prinsip Arsitektur Tepian Air, hasil studi menunjukkan bahwa dalam pengembangan waterfront penting untuk mengharmoniskan antara kota/lahan dan air agar keduanya dapat berperan timbal balik. Hubungan timbal balik antara keduanya dapat mewujudkan suatu lingkungan yang tertata dengan baik juga menghadirkan fungsi-fungsi yang mewadahi kegiatan dalam kawasan tepi air secara lebih efektif dan fungsional (Lubis, 2018).

Pengertian waterfront dalam Bahasa Indonesia secara harafiah adalah daerah tepian, bagian kota yang berbatasan dengan air, daerah pelabuhan. Urban waterfront mempunyai arti suatu lingkungan perkotaan yang berada di tepi atau dekat wilayah perairan, misalnya lokasi di area pelabuhan besar di kota metropolitan (Wrenn,1983). The Dynamic area of the cities and towns where land and water meet (Breen \& Rigby, 1994). Betikut tahapan dalam penelitan sebagai berikut:

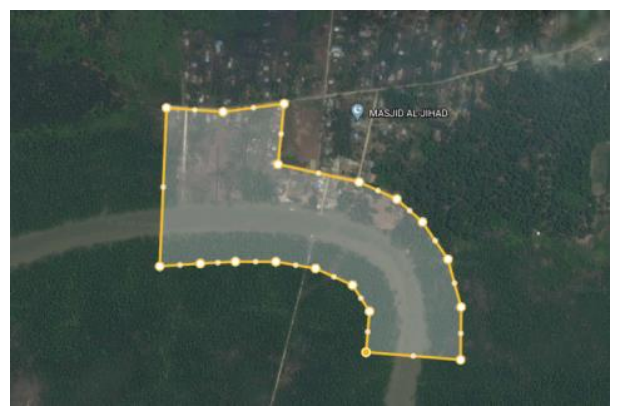

Gambar 5. Lokasi Site

Sumber: Google Earth 2020

Pengumpulan data survei didukung dengan melakukan dokumentasi terhadap hal-hal yang berhubungan dengan site dan perancangan. Dokumentasi yang dilakukan dapat berupa gambar, video, dan sketsa. Metode ini untuk mendapatkan informasi lebih detail dari hasil pengamatan yang dilakukan. Metode pengumpulan ini dilakukan dengan mencari studi kasus yang berkaitan dengan perancangan baik fungsi maupun tema.

Strategi penataan kawasan wisata Desa Bokor di Kabupaten Kepulauan Meranti yang sesuai dengan penerapan arsitektur tepian air, maka diperlukan langkah-langkah sebagai berikut. Langkah pertama dalam proses perancangan Kawasan Wisata Desa Bokor adalah mengkaji studi literatur yang berhubungan dengan 
fungsi dan tema perancangan dan mengambil inti sari dari studi literatur tersebut untuk dijadikan landasan dalam perancangan. Pada langkah selanjutnya dari Peracangan Kawasan Wisata Desa Bokor ini di perlukan survei lapangan untuk mengetahui kesesuaian studi literatur yang di peroleh dengan data lapangan secara sistematis. Survei site memperhatikan kondisi lingkungan sekitar agar mendapatkan penanganan desain yang tepat. Analisa fungsi kawasan dalam tahap langkah perancangan dilaksanakan sebagai dasar untuk mengetahui kegiatan yang akan akomodasikan dalam perancangan. Untuk mengetahui fungsi rancangan yang dibutuhkan untuk mewadahi bermacam kegiatan yang akan dilakukan dalam Kawasan Wisata Desa Bokor. Analisa site merupakan analisa karakter-karakter yang terdapat pada lokasi terpilih untuk dijadikan lahan yang tepat dalam perancangan Kawasan Wisata Desa Bokor. Analisa ini bertujuan untuk mengetahui potensi site, dan memecahkan permasalahan yang terdapat di lokasi site. Dari sini dapat mengetahui tata guna Kawasan yang tepat. Mengelompokan ruang berdasarkan sifat dan fungsi untuk mengakomodasi berbagai kegiatan yang terjadi di kawasan wisata ini. Hasil berupa pemetaan pengelompokan ruang berdasarkan sifat dan fungsi tersebut. Penzoningan bertujuan untuk membedakan beberapa zona pada kawasan. Hal ini dilakukan untuk mengetahui perletakan ruang yang sesuai dengan kondisi tapak. Pada tahap perancangan, konsep merupakan hal yang paling terpenting karena konsep merupakan dasar dari penerapan beberapa prinsip arsitektur tepian air terhadap Kawasan Wisata Desa Bokor. Bentukan ini didasarkan dari proses transformasi pada konsep dan tema. Sistem utilitas pada perancangan Kawasan Wisata Desa Bokor, selain menerapkan sistem utilitas umum yaitu, sistem air bersih, sistem air kotor dan sistem pengolahan sampah.

Menurut Yahya (2013) suatu kawasan yang berada ditepian air dapat diartikan sebagai berikut :

1. Kawasan yang dinamis dan unik dari suatu daerah di mana daratan dan air bertemu dan harus dipertahankan keunikannya.

2. Kawasan yang dapat meliputi bangunan atau aktivitas yang tidak harus secara langsung berada di atas air.

Arsitektur tepian air secara harfiah berada di daerah tepian yang berbatasan dengan air di daerah pelabuhan (Echols dalam Tangkuman, 2011). Direktorat Jenderal Pesisir dan Pulau-Pulau Kecil dalam Pedoman Kota pesisir dalam Putra (2017) mengemukakan bahwa arsitektur tepian air merupakan suatu area yang terletak berbatasan dengan air dan berorientasi menghadap ke laut, sungai, danau dan sejenisnya. Dari dua pengertian di atas dapat disimpulkan arsitektur tepian air itu merupakan suatu kawasan atau area serta bangunannya yang berada pada pertemuan antara daratan dan perairan.

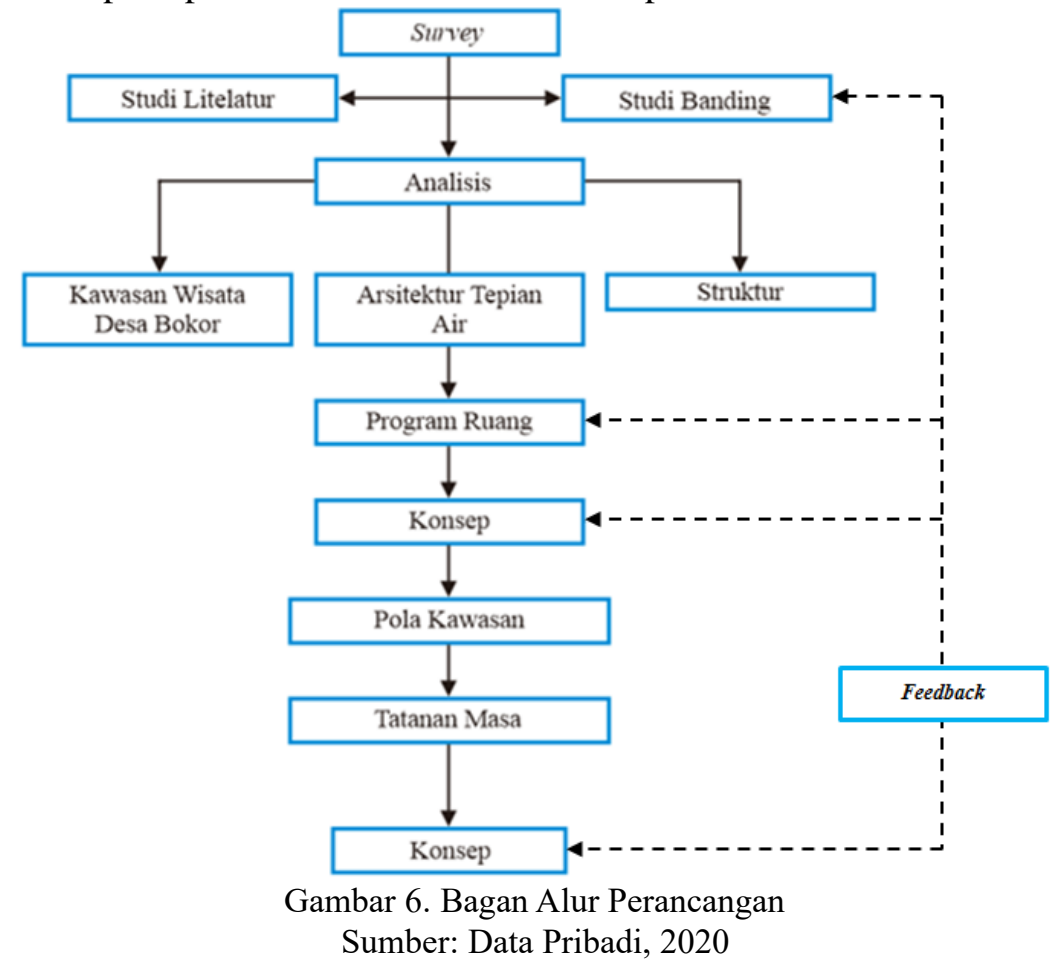




\section{Hasil dan Pembahasan}

\subsection{Analisis}

\subsubsection{Lokasi Perancangan}

Lokasi berada di Jl. Bathin galang, Desa Bokor, Kecamatan Rangsang Barat, Kabupaten Kepulaun Meranti, Provinsi Riau dengan data luas lahan $\pm 150.000 \mathrm{~m}^{2}$ (15 HA), koefisien dasar bangunan (KDB) $60 \%$ dan memiliki kontur tanah yang relatif datar karena berada pada area pesisir. Site merupakan lahan kosong dan juga permukiman warga. Batas-batas fisik tapak terpilih pada arah utara berbatasan dengan permukiman warga dan kantor pemerintahan, pada arah timur berbatasan dengan pemukiman warga dan hutan mangrove, pada arah selatan berbatasan dengan hutan mangrove, pada arah barat berbatasan dengan hutan mangrove. Adapun potensi lokasi yang menjadikan lokasi ini terpilih untuk perancangan Kawasan Wisat Desa Bokor adalah, Desa Bokor sendiri memiliki festival musik yang mencakup internasional, memilikir beberapa festival budaya, site berupa lahan kosong dan hutan mangrove, site memiliki hutan mangrove yang masih terjaga, site bisa diakses melalui jalur darat dan jalur air.

Berdasarkan PerDa Kabupaten Kepulauan Meranti. Garis Sempadan Laut/Sungai (Pasal 20). Garis sempadan laut yang terpengaruh pasang surut air laut ditetapkan 100 (seratus) meter dari tepi lajur pengaman laut dan/atau dari titik pasang tertinggi yang berfungsi sebagai jalur hijau. Garis sempadan sungai ditetapkan 50 (lima puluh) meter dari titik pasang tertinggi ke arah darat. Garis sempadan sungai dan laut dapat digunakan dengan petunjuk instansi yang terkait (DPRD Kabupaten Kepulauan Meranti \& Bupati Kepulauan Meranti, 2012).

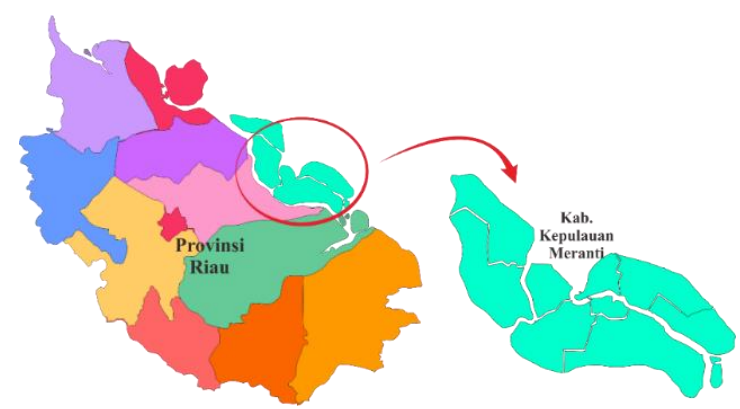

Gambar 7. Lokasi Site

Sumber: Data Pribadi, 2020

\subsubsection{Kebutuhan Ruang}

Besaran kebutuhan ruang pada Kawasan Wisata Desa Bokor ini terbagi atas fasilitas utama, fasilitas pendukung, fasilitas penunjang, dan perhitungan kebutuhan parkir. Perhitungan besaran ruang ini berdasarkan kepada Neufert Architect Data (NAD), Time Saver Standard (TSS), Asumsi (AS) berdasarkan studi banding.

Tabel 1. Kebutuhan Ruang

\begin{tabular}{|c|c|}
\hline Fasilitas & Luas \\
\hline Zona Pengunjung & $2673.3 \mathrm{~m} 2$ \\
\hline $\begin{array}{c}\text { Zona Ruang Staff Dan } \\
\text { Pelayanan }\end{array}$ & $2460.1 \mathrm{~m} 2$ \\
\hline Zona Parkir & $2500 \mathrm{~m} 2$ \\
\hline Total & $7633.4 \mathrm{~m} 2$ \\
\hline
\end{tabular}

Sumber: Data Pribadi, 2020

Berdasarkan PerDa Kabupaten Kepulauan Meranti. Garis Sempadan Laut/Sungai (Pasal 20). Garis sempadan laut yang terpengaruh pasang surut air laut ditetapkan 100 (seratus) meter dari tepi lajur pengaman laut dan/atau dari titik pasang tertinggi yang berfungsi sebagai jalur hijau. Garis sempadan sungai ditetapkan 50 (lima puluh) meter dari titik pasang tertinggi ke arah darat. Garis sempadan sungai dan laut dapat digunakan dengan petunjuk instansi yang terkait.

penata panggung dapat merancangkan karyanya berdasarkan lakon yang akan disajikan dengan baik. Bentuk-bentuk panggung (Emil, 1993) :

A. Bentuk Segi Empat 


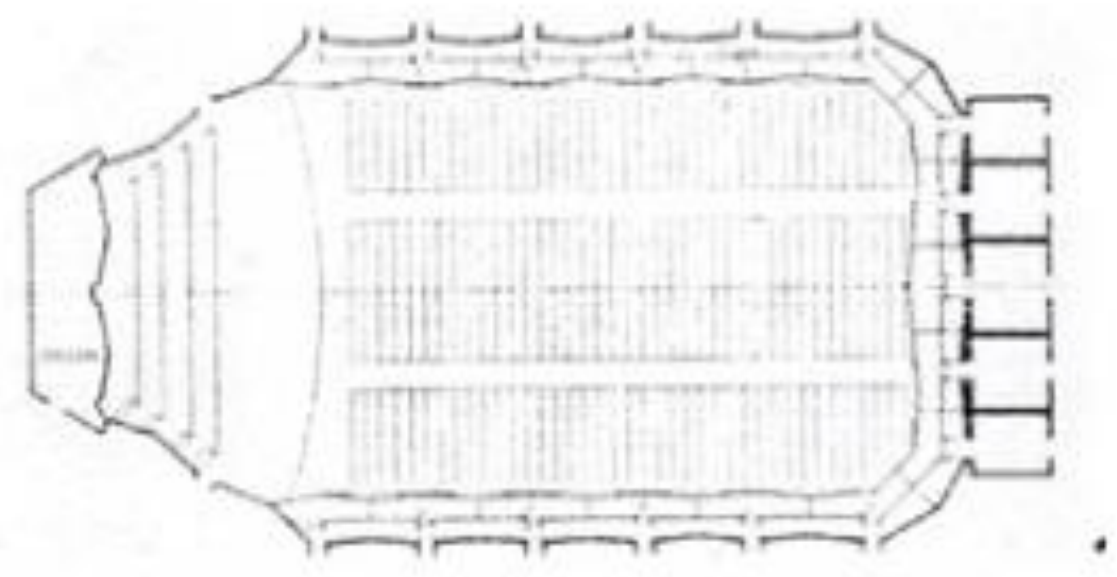

Gambar 8. Panggung Segi Empat Sumber: http://bit.ly/344sBtJ, 2020

B. Bentuk Kipas

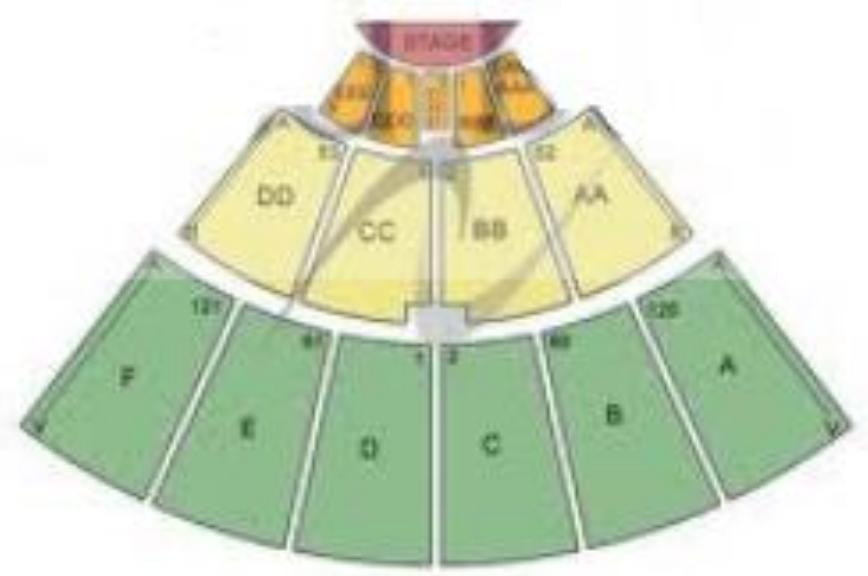

Gambar 9. Panggung Bentuk Kipas

Sumber: http://bit.ly/344sBtJ, 2020

C. Auditorium 3600

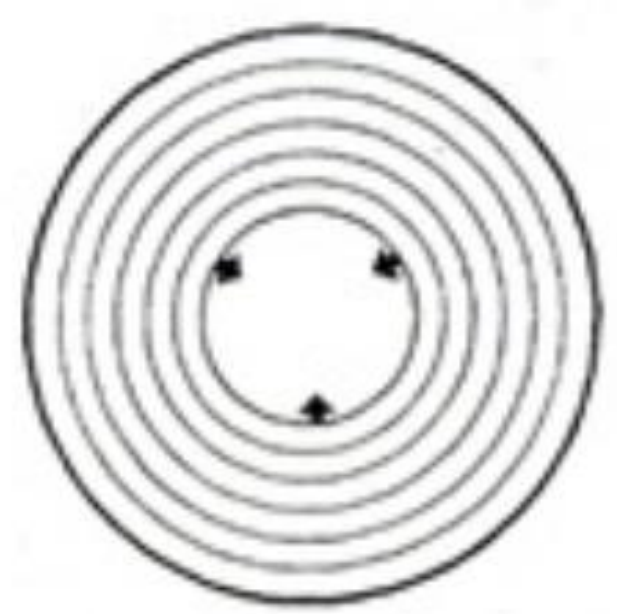

Gambar 10. Panggung Bentuk Auditorium Sumber: http://bit.ly/344sBtJ, 2020 
D. Panggung Terbuka

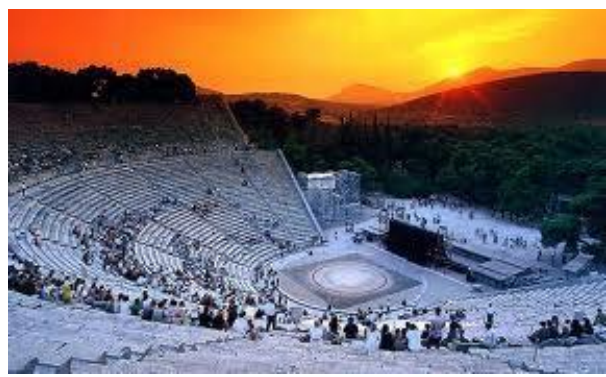

Gambar 11. Panggung Terbuka

Sumber: http://bit.ly/344sBtJ, 2020

E. Ruang Arena

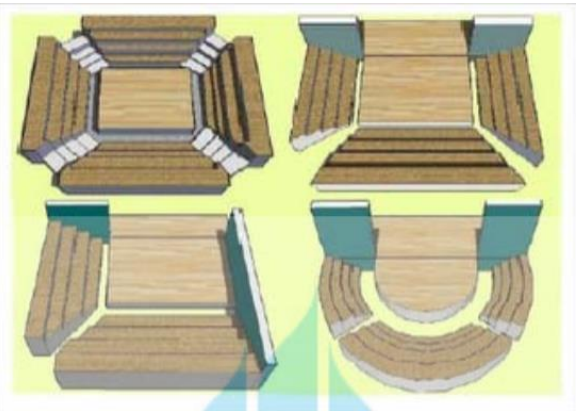

Gambar 12. Panggung Ruang Arena

Sumber: http://bit.ly/344sBtJ, 2020

Tentunya banyak menghabiskan waktu, oleh karena itu, disediakan fasilitas untuk sholat bagi pengunjung. Pada Tabel 2 akan dijelaskan kebutuhan ruang dan standar yang akan digunakan pada Masjid :

Tabel 2. Standar Besaran Masjid

\begin{tabular}{|l|}
\hline \multicolumn{3}{|c|}{ Nama Ruang } \\
Ruang sholat arahnya mengikuti \\
suatu ruang yang lebih kecil untuk \\
satu orang yang berukuran 0,85 $\mathrm{m}^{2}$. \\
Ruang itu merupakan ruang persegi \\
panjang yang arahnya berkiblat ke \\
Makkah. Tempat sujud (mihrab) \\
berada didekat ruang keluar, \\
disamping mimbar yang biasa \\
digunakan untuk sholat jumat. Dan \\
tempat sholat antara laki-laki dan \\
perempuan dipisah (Sumber: Ernst dan \\
Peter Neufert, 2002:249). \\
Perhitungan luasan ruang sholat \\
adalah dengan menggunakan \\
perhitungan jumlah orang yang sholat \\
dikalikan dengan standar dimensi per \\
orang yaitu 0,85 m².
\end{tabular}




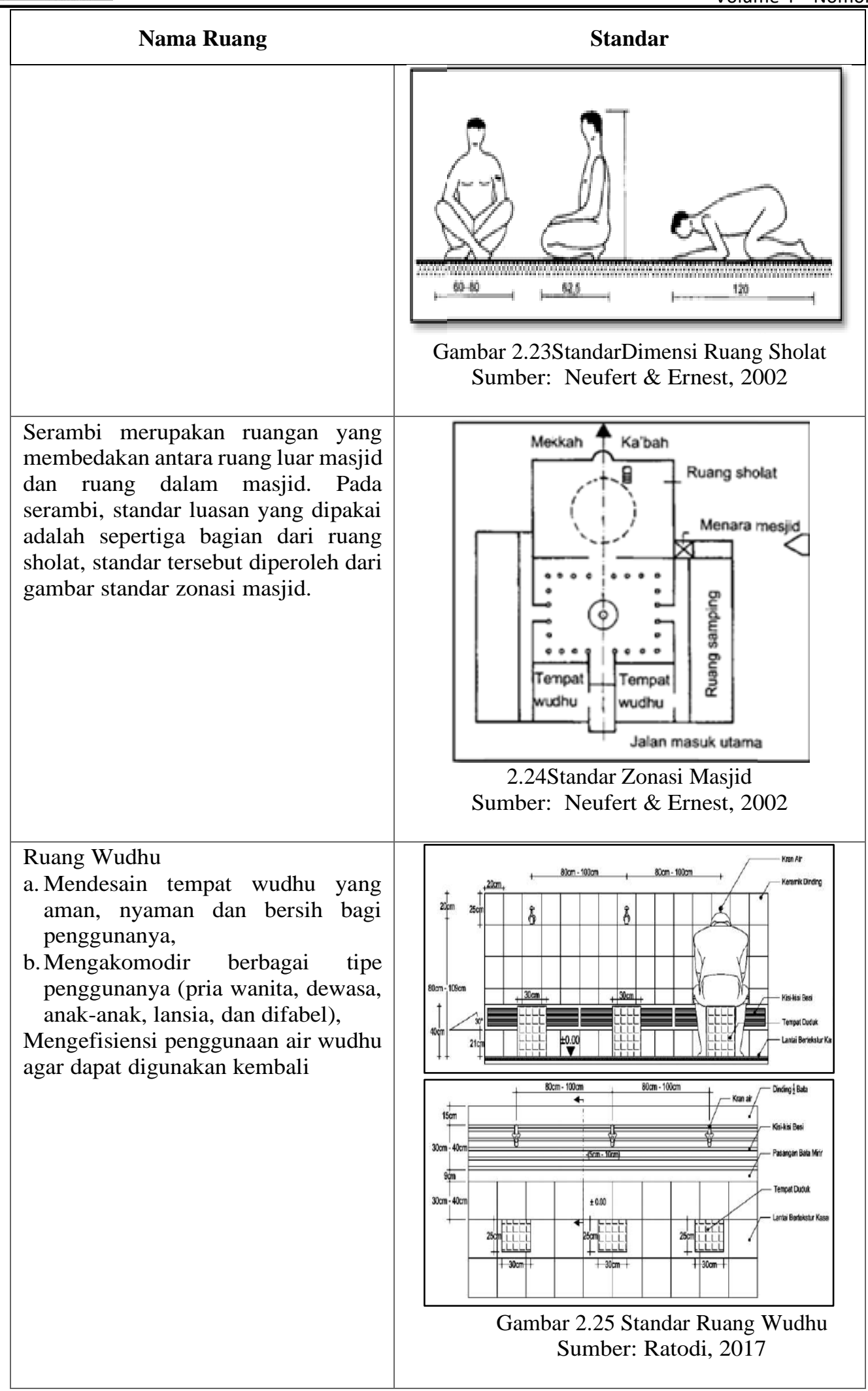




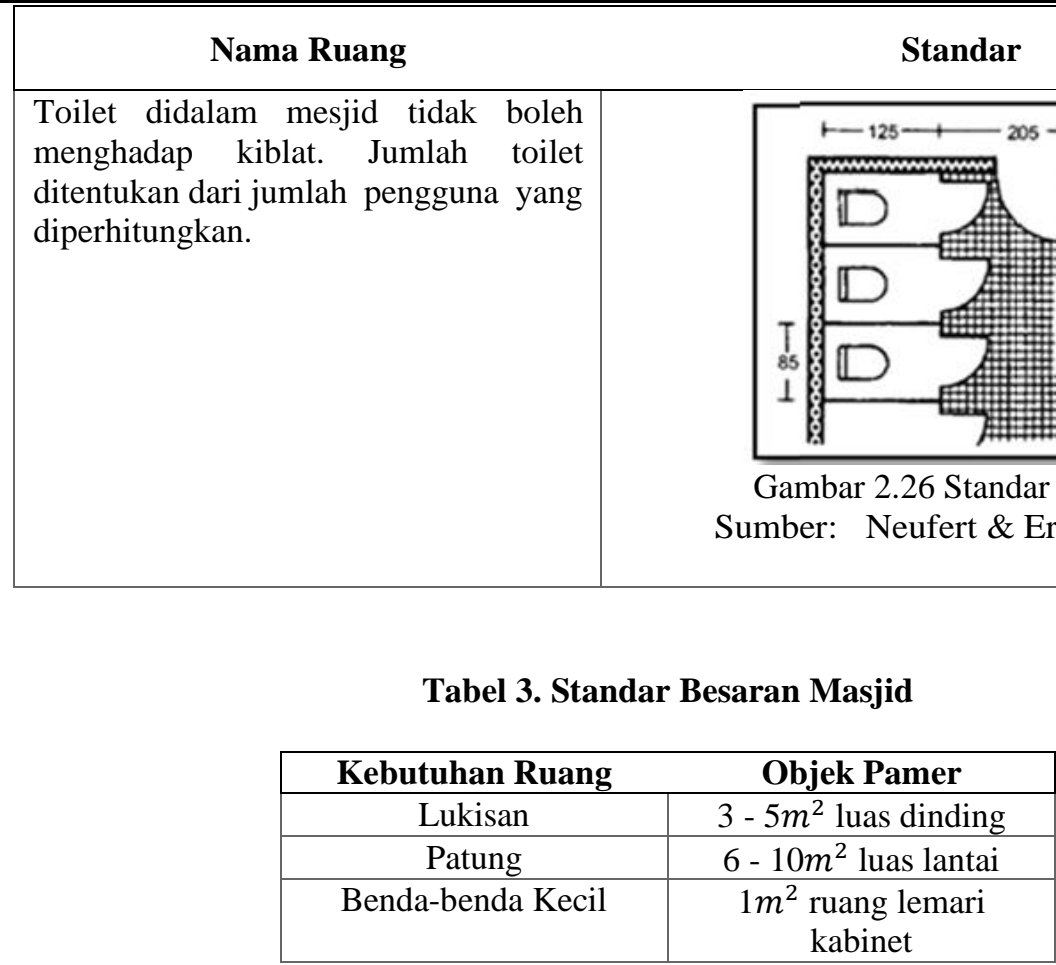

Sumber: Ching, 2008

Dermaga harus direncanakan sedemikian rupa sehingga kapal dapat merapat dan bertambat serta melakukan kegiatan dipelabuhan dengan aman, cepat dan lancar (Triatmodjo. 2009).

A. Wharf, Dermaga bentuk wharf ini berbenuk memanjang.

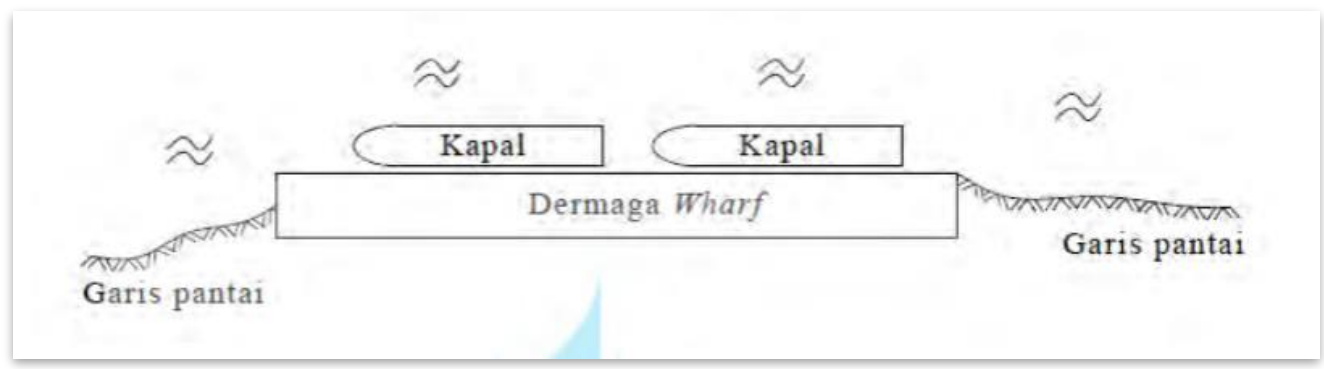

Gambar 13. Dermaga Tipe Wharf

Sumber: http://bit.ly/344sBtJ, 2020

B. Pier, Pier adalah dermaga yang membentuk sudut terhadap garis pantai.

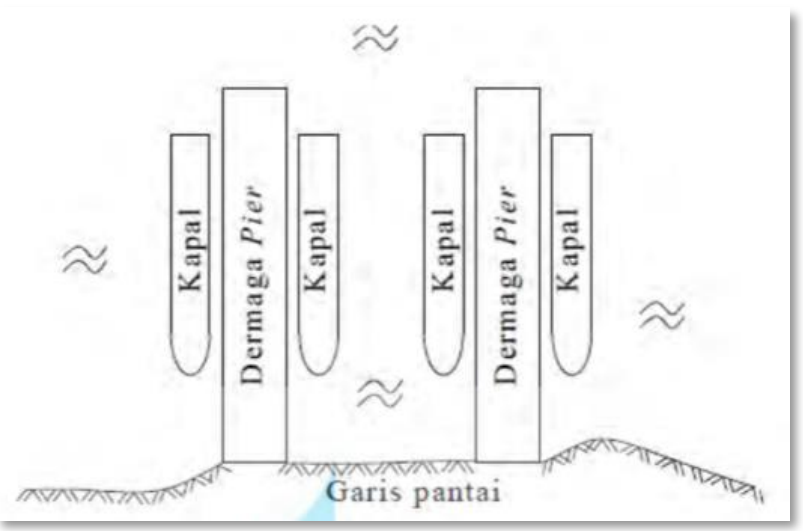

Gambar 14. Dermaga Tipe Pier

Sumber: http://bit.ly/344sBtJ, 2020 
C. Jetty, Dermaga berbentuk jetty adalah adalah dermaga yang membentuk sudut terhadap garis pantai.

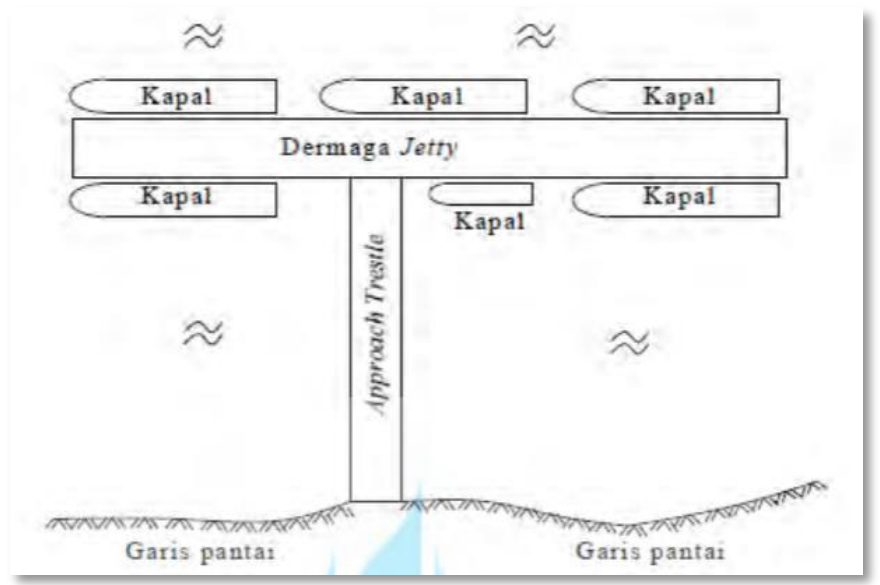

Gambar 15. Dermaga Tipe Jetty

Sumber: http://bit.ly/344sBtJ, 2020

\subsubsection{Aksebilitas dan Sirkulasi}

Pencapaian menuju tapak cukup dengan moda kendaraan pribadi dan juga melalui kapal yang bertujuan langsung kelokasi. Hal ini dikarenakan perletakan lokasi yang berada didesa, sehingga tidak adanya kendaraan umum. Dari jalur darat sendiri bisa di akses menuju kawasan melaui Jalan Bathin Galang. Sedangkan pada jalur air sendiri diakses melalui sungai Bokor tepatnya dipelabuhan Sake Due.

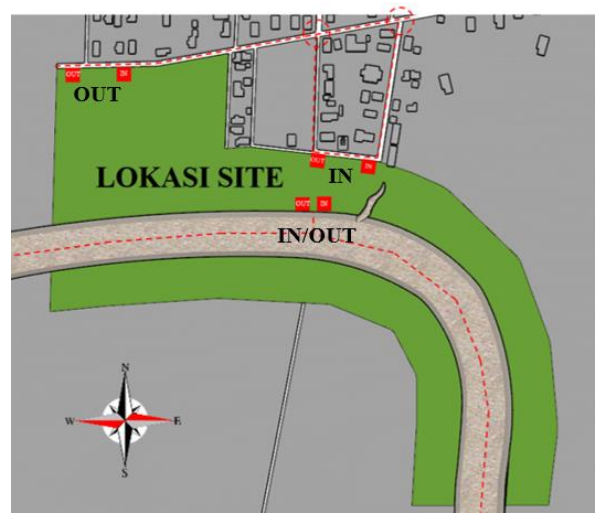

Gambar 16. Aksebilitas dan Sirkulasi Sumber: Data Pribadi, 2020

Akses melalui jalur darat sudah memiliki jalan yang baik sehingga memudahkan pengunjung untuk menuju kawasan. Sedangkan akses melalui jalur air sendiri melalui pelabuhan sake due, yang dimana pelabuhan yang digunakan oleh pengunjung ini masih sangat minim apa bila air sedang surut, sehingga perlunya perbaikan pada pelabuhan agar bisa tetap digunakan oleh pengunjung walaupun air sedang surut. Yang dimana pelabuhan harus menggunakan ponton agar bisa mengikuti pasang surut air.

\subsubsection{Visual}

Pemandangan ke luar pada sisi utara site adalah pemukiman warga dan kantor pemerintahan, sedangkan pada sisi selebihnya adalah hutan karet. Sedangkan pada sisi timur terdapat beberapa permukiman warga dan hutan mangrove. Hal ini memiliki nilai lebih pada site karena akan memberikan sebuah objek wisata mangrove pada Perancangan Kawasan Wisata Desa Bokor. Karena dinyatakan belum cukup menarik pada kawasan, sehingga sebagai tanggapan rancangan maka pada lokasi tapak akan dirancang penataan lansekap yang menarik sehingga pengguna juga akan dimanjakan oleh view yang berada dalam objek perancangan nantiknya. Perlunya penataan pada kawasan agar view yang dapat lebih menarik, hal ini dikarenakan kawasan berada di daerah perdesaan, sehingga tidak ada view yang menarik untuk dapat dinikmati oleh pengunjung. Maka dari itu diperlukan perancangan ini agar view didalam kawasan mampu memberikan kesan nyaman pada pengunjung. 


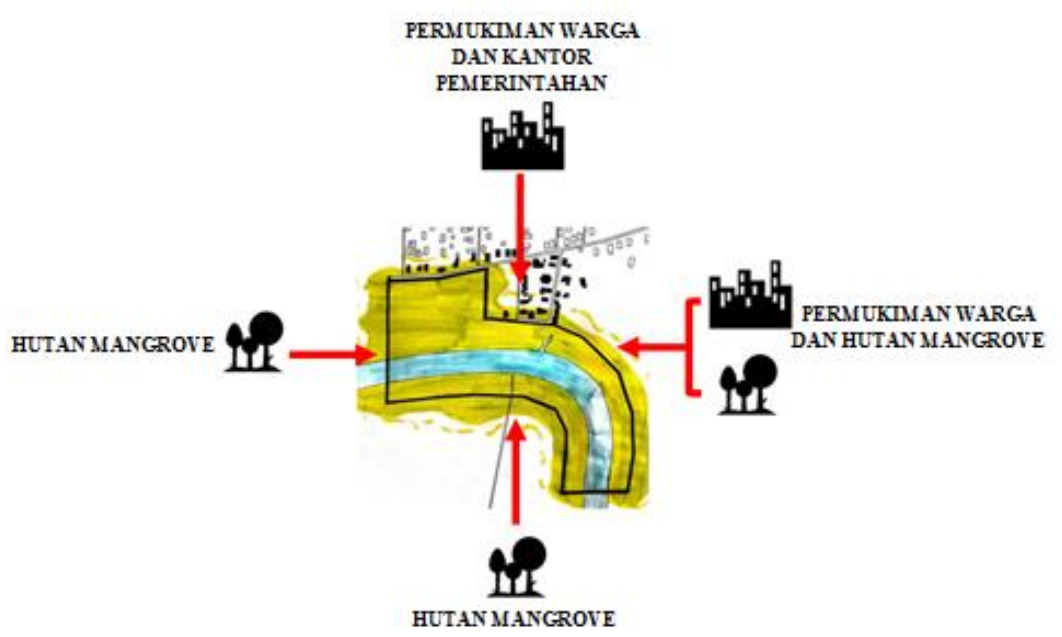

Gambar 17. Visual Lokasi Site

Sumber: Data Pribadi, 2020

\subsubsection{Kontur}

Site perancangan merupakan lahan kosong dan juga permukiman masyarakat. Site juga memiliki kontur yang datar seperti gambar dibawah.

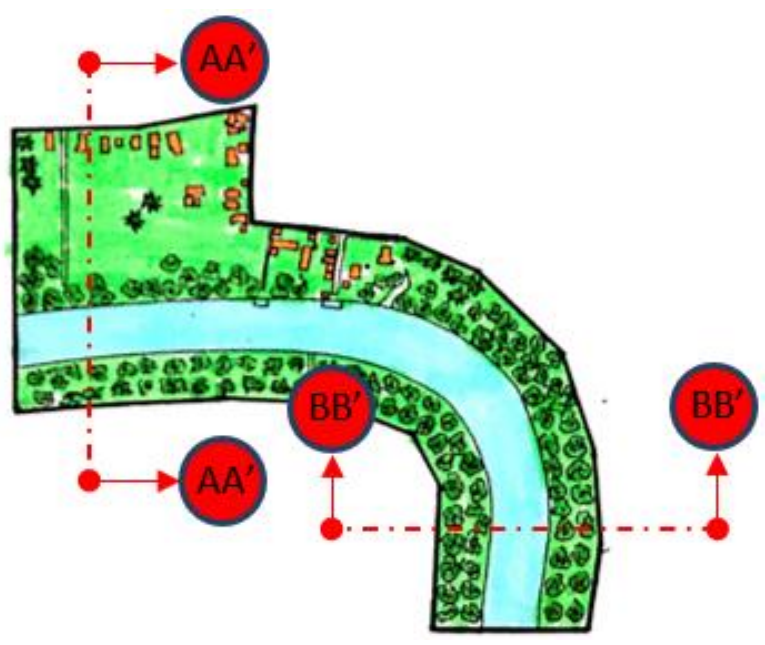

Gambar 18. Site Terpilih

Sumber: Data Pribadi, 2020

Pada site kawasan adalah lahan kosong dan memiliki beberapa pemukiman masyarakat, sehingga memudahkan proses perancangan. Dan nantiknya untuk permukiman masyarakat yang harus digusur akan dialokasikan ketempat yang lebih baik agar mempermudah proses perancangan.

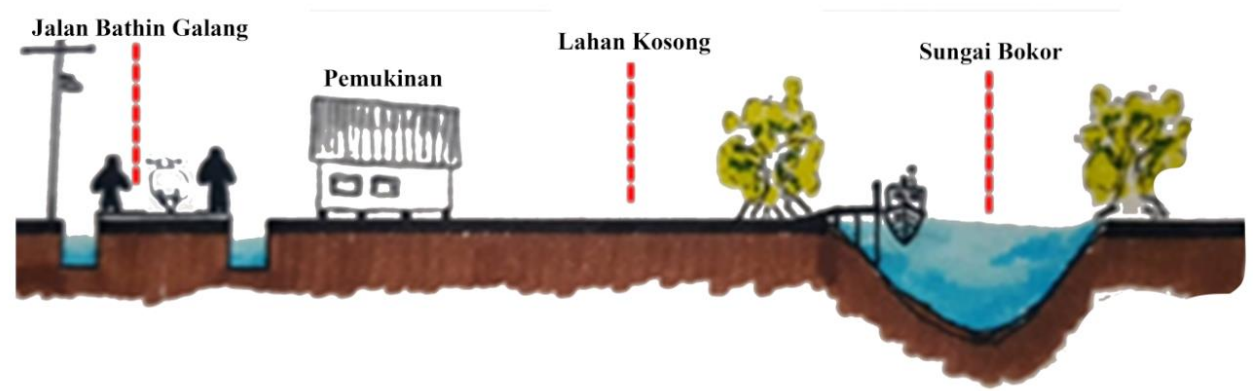

Gambar 19. Potongan Kawasan AA'

Sumber: Data Pribadi, 2020

Pada sisi tepian sungai ditumbuhi tanaman mangrove sehingga beberapa titik ditepian sungai yang ditanami mangrove harus ditebang karena akan dijadikan spot homestay. Dan hal ini juga tidak sampai merusak kelestarian mangrove itu sendiri dan akan tetap dilestarikan sebagai objek wisata. 


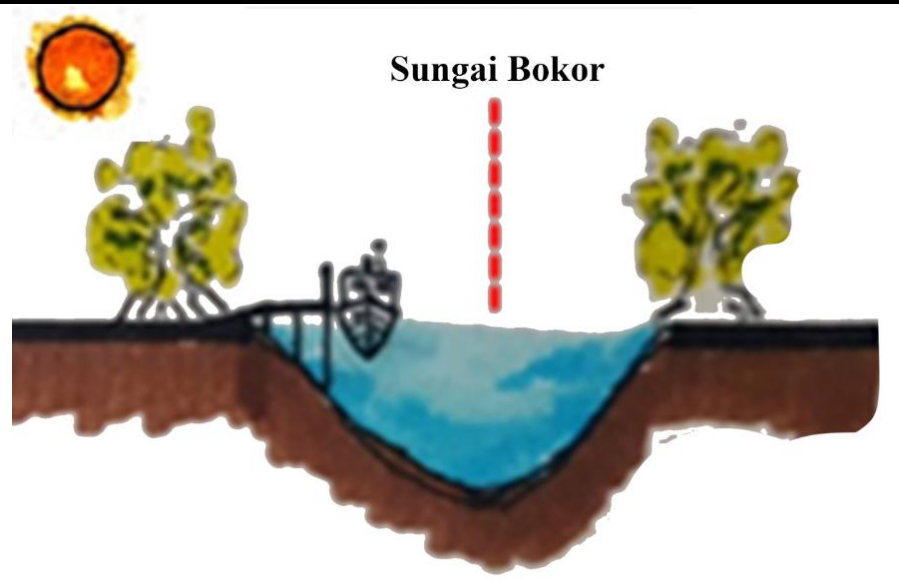

Gambar 20. Potongan Kawasan BB'

Sumber: Data Pribadi, 2020

\subsubsection{Kebisingan}

Pada kawasan perancangan kebisingan yang dihasilkan oleh pengendara yang berada pada Jalan Bathin Galang, dan juga pada Jalan Pelabuhan. Dan kebisingan yang dihasilkan tidak lah besar, dikarenakan pada Desa Bokor tidak adanya kendaraan umum dan juga kendaraan pribadi seperti mobil, sehingga kebisingan yang dihasilkan tidak cukup besar.

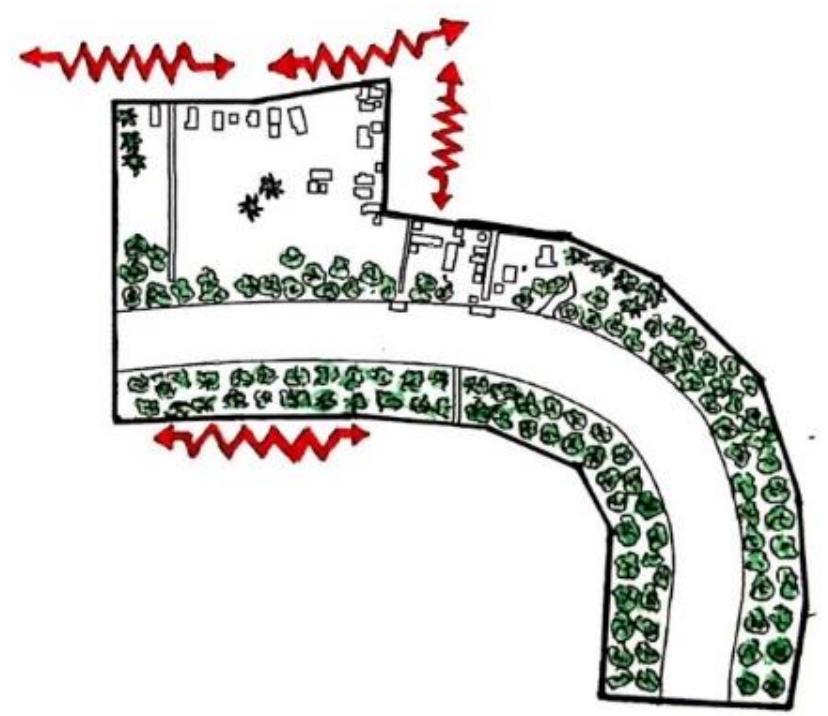

Gambar 21. Kebisingan

Sumber: Data Pribadi, 2020

Tabel 4. Tanggapan Terhadap Kebisingan

\begin{tabular}{|c|c|}
\hline Tanggapan Permasalahan & Solusi Arsitektural \\
\hline Vegetasi & $\begin{array}{c}\text { Tingkat kebisingan sedikit dikurangi } \\
\text { menggunakan sususan vegetasi agar pengunjung } \\
\text { tidak merasa terganggu saat berkomunikasi dan } \\
\text { berinteraksi. }\end{array}$ \\
\hline $\begin{array}{c}\text { Gubahan Bentuk Fisik } \\
\text { Tapak }\end{array}$ & $\begin{array}{c}\text { Selain penanaman vegetasi, hal lain yang dapat } \\
\text { dilakukan berupa perubahan fisik dari tapak itu } \\
\text { sendiri. Misalnya dengan memberikan gundukan } \\
\text { tanah, sehingga gundukan tanah tersebut dapat } \\
\text { sedikit membatasi suara yang masuk kedalam } \\
\text { tapak. }\end{array}$ \\
\hline
\end{tabular}




\subsubsection{Matahari dan Angin}

Pada kawasan ini pemanfaatan matahari dilakukan untuk proses penjemuran bahan-bahan kerajinan yang terdapat pada bangunan pusat kerajinan, sedangkan pemanfaatan angin pada kawasan digunakan untuk menjaga kondisi thermal pada bangunan yang ada dengan bukaan yang besar pada bangunan.

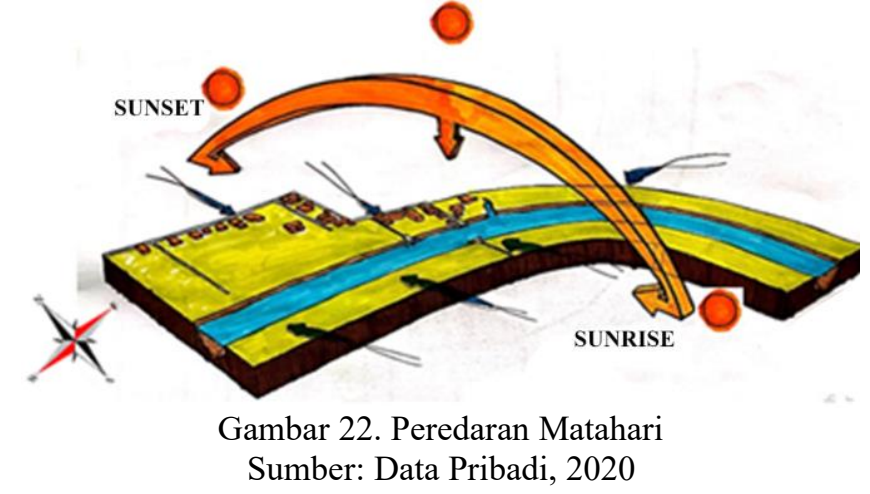

\subsubsection{Vegetasi}

Pada kawasan ini tanaman yang dominan adalah mangrove, serta ada pula pohon kelapa di beberapa titik, vegetasi tersebut tidak mampu menjadi penahan kebisingan alami, sehingga vegetasi asli pada kawasan akan dipertahankan namun akan ditambahkan dengan bebrapa vegetasi yang mampu menyaring kebisingan untuk masuk kedalam kawasan. Dan vegetasi asli tetap disusun sesui konsep dan prinsip arsitektur tepian air nantinya, jika perlu akan dilakukan penambahan vegetasi sesuai kebutuhan penataan pada kawasan seperti penambahan bunga-bunga dan tanaman hias untuk taman dan tanaman peneduh.

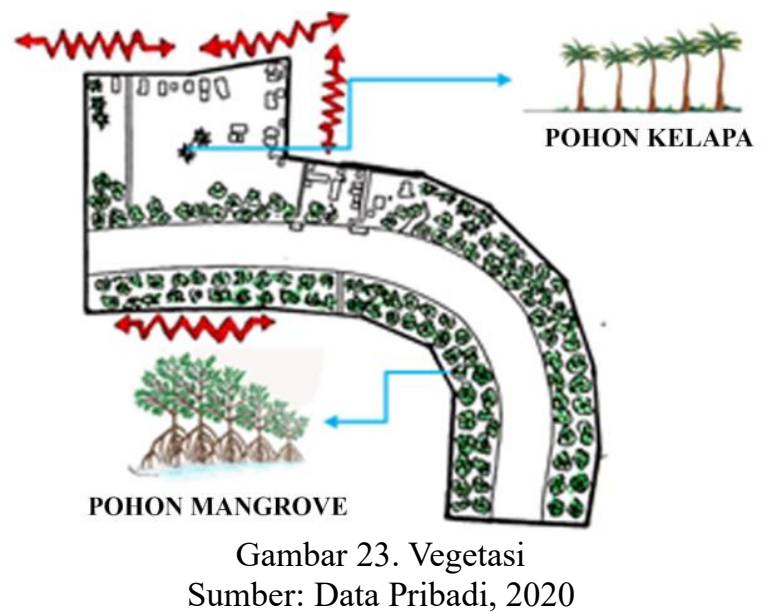

Tabel 5. Tanggapan Terhadap Vegetasi

\begin{tabular}{|c|c|}
\hline Tanggapan Permasalahan & Solusi Arsitektural \\
\hline $\begin{array}{c}\text { Vegetasi yang ada } \\
\text { dipindahkan ke tempat yang } \\
\text { baru untuk menyesuaikan } \\
\text { dengan bentukan dan } \\
\text { peruntukan pada lokasi } \\
\text { perancangan. }\end{array}$ & $\begin{array}{c}\text { Menambah jumlah vegetasi guna membantu } \\
\text { sebagai peneduh, dan estetika pada lokasi } \\
\text { perancangan. }\end{array}$ \\
\hline $\begin{array}{c}\text { Beberapa vegetasi diatur } \\
\text { sedemikian rupa digunakan } \\
\text { sebagi pembentuk bayangan } \\
\text { matahari, sehingga vegetasi } \\
\text { tersebut dapat merduksi } \\
\text { panas. }\end{array}$ & $\begin{array}{c}\text { Pemanfaatan vegetasi sebagai pembatas, pereduksi } \\
\text { panas untuk melindungi kegiatan pengunjung pada } \\
\text { lokasi perancangan. }\end{array}$ \\
\hline
\end{tabular}

Sumber: Data Pribadi, 2020 


\subsubsection{Dasar Perancanagan}

Kawasan Wisata Desa Bokor merupakan tempat dimana melakukan aktifitas rekreasi, edukasi, dan juga hunian sementara bagi para pengunjung. Dengan adanya perancangan ini mampu mewadahi pusat kegiatan dan menambah fasilitas dari setiap kegiatan yang mencangkup dalam pelestarian budaya. Tujuan dibuatnya kawasan ini adalah sebagai wadah pelestarian budaya dan pendidikan. Sesuai dengan tema yang digunakan pada Perancagan Kawasan Wisata Desa Bokor yaitu Arsitektur Tepian Air. Adapun karakteristik umumnya adalah Lokasinya yang berada di tepian air seperti sungai. Kawasan yang berupa pelabuhan, pariwisata. Fungsi utama sebagai area permukiman, pariwisata dan pelabuhan. Orieantasi selalu menghadap ke perairan. Pembangunan di lakukan secara vertikal dan horizontal.

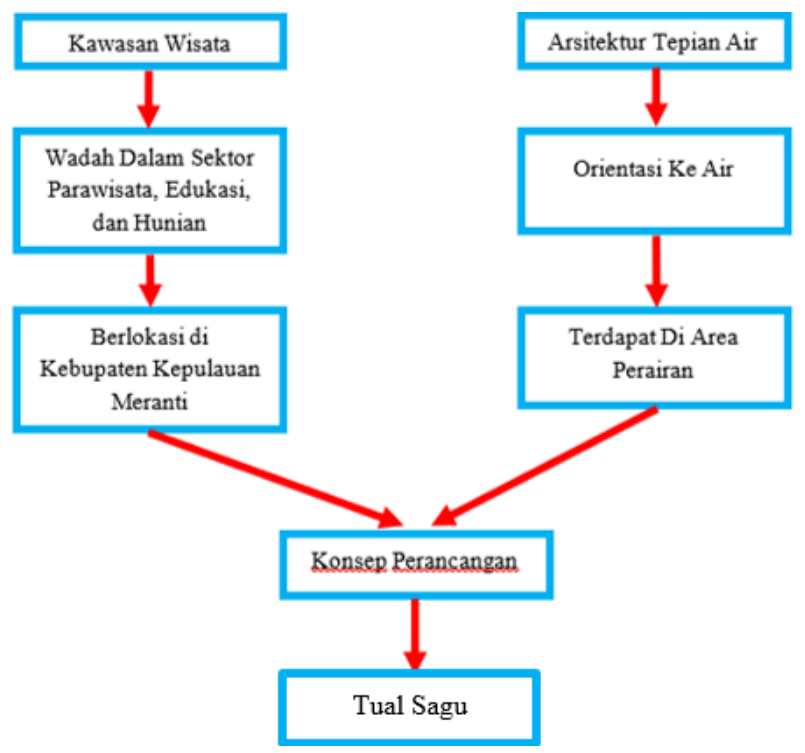

Gambar 24. Bagan Konsep (Sumber: Data Pribadi, 2020)

Dengan menggunakan karakteristik sebagai dasar Perancangan Kawasan Wisata Desa Bokor. maka konsep yang akan digunakan adalah "Tual Sagu". Yang dimana Pemilihan konsep ini didasari dari pohon sagu, yang dimana pohon sagu adalah pohon endemik yang ada di Kabupaten Kepulauan Meranti. Dan juga pohon sagu adalah menjadi iconik dari Kabupaten Kepulauan Meranti.

\subsubsection{Konsep Kawasan}

Proses pengembangan konsep dasar "Tual Sagu" guna mendapatkan bentukan menggunakan ciri arsitektur tepian air yaitu, kawasan yang berlokasi ditepian air, area pelabuhan, fungsi utama sebagai kawasan wisata, orientasi ke perairan, pembangunan yang kearah vertikal dan horizontal. Dari konsep dasar "Tual Sagu" ini kemudian dikembangkan lagi menjadi sebuah pola kawasan dengan membentuk pola melengkung pada kawasan guna dijadikan sebagai zona dari setiap fungsi yang ada pada kawasan. Dan pola diambil dari bentukan "Tual Sagu". Visualisasi pola tersebut dilihat pada gambar dibawah :

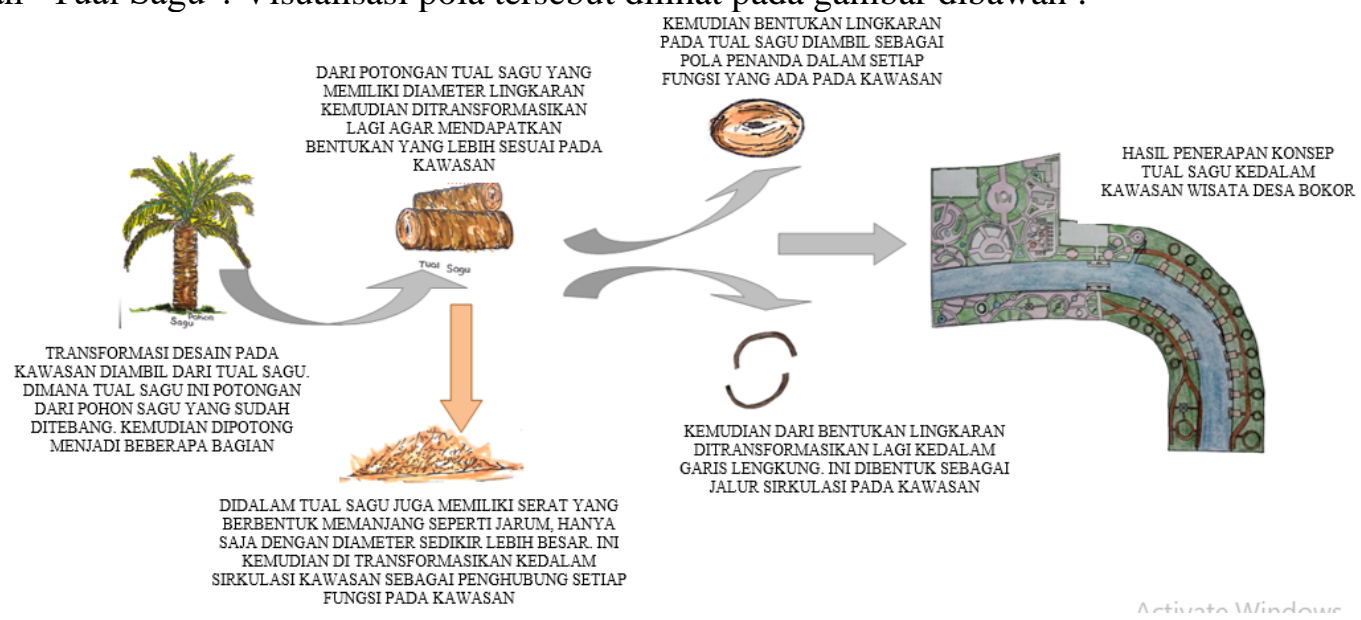

Gambar 25. Proses Transformasi Desain Kawasan

Sumber: Data Pribadi, 2020 


\subsubsection{Konsep Rencana Tapak}

Pengembangan bentuk tapak juga merupakan hasil respon dari hasil analisa tapak yang juga merupakan hasil pengembangan konsep yang memiliki bentuk dan komposisi dan dimana masing-masing fungsi saling tehubung guna menekankan konsep yaitu "Tual Sagu". Dapat dilihat pada gambar 18:

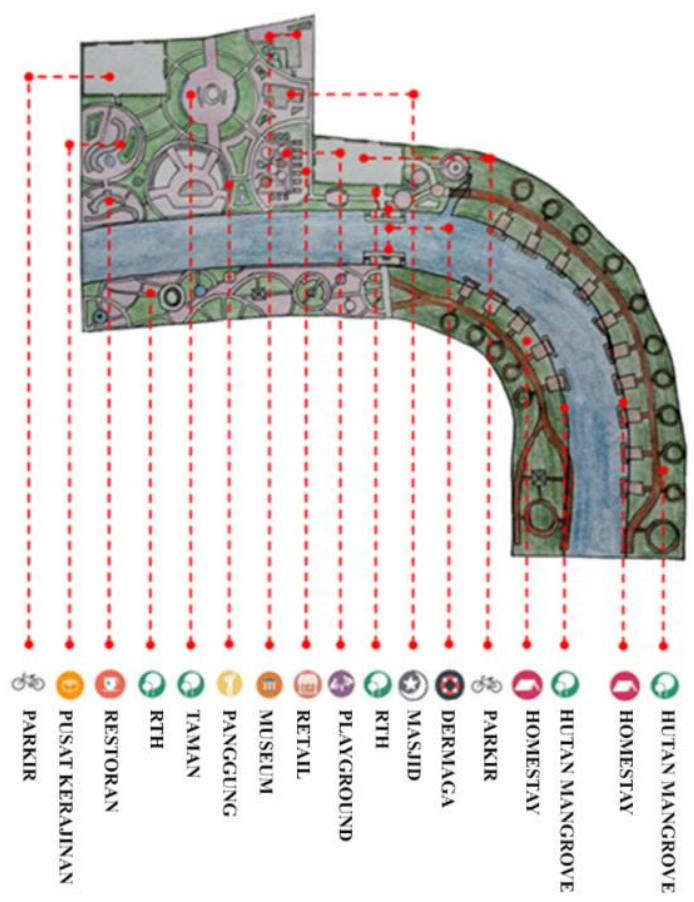

Gambar 26.Proses Pengembangan Tapak Lokasi Perancangan

Sumber: Data Pribadi, 2020

\subsubsection{Konsep Fungsi Bangunan}

Tranformasi bentuk pada fungsi perancangan diambil dari bentukan tual sagu sendiri dengan bentukan bulat atau memiliki lengkung di setiap bidangnya. Dan bentukan dari setiap fungsi tidak seutuhnya menyerupai bentukan dari tual sagu dan bentukan setiap fungsi akan di transformasikan sesuai dengan fungsi pada bangunan. Ciri pada bangunan yang dimana memiliki bidang lengkung pada setiap fungsi sehingga tidak terlepas dari konsep tual sagu.

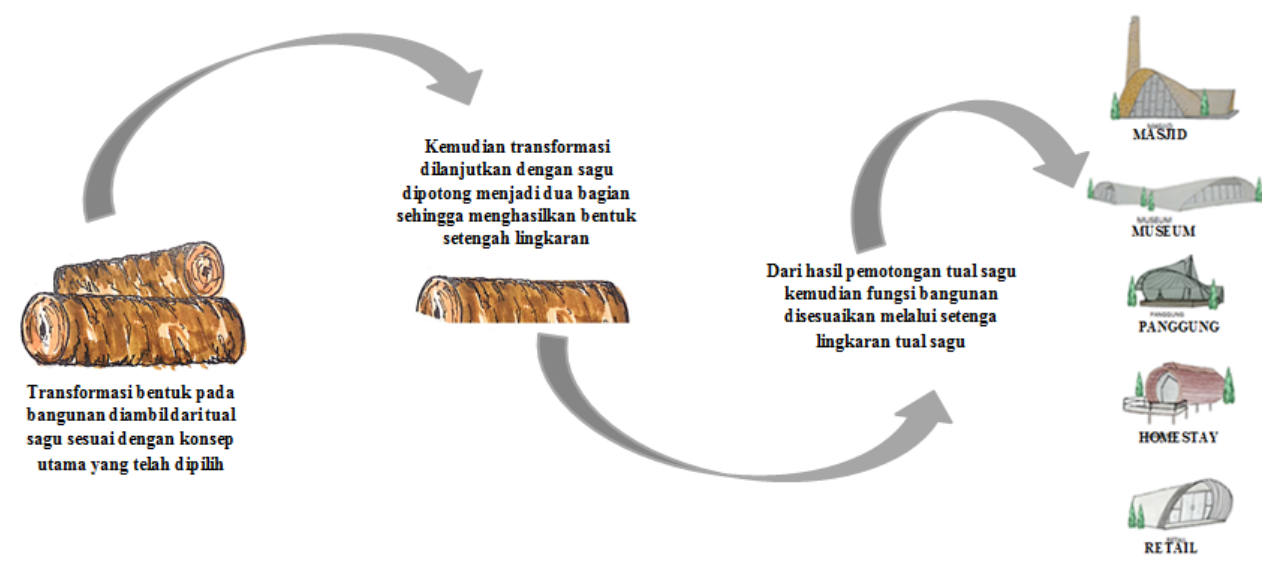

Gambar 27. Proses Transformasi Desain Fungsi Objek Perancangan Sumber: Data Pribadi, 2020 


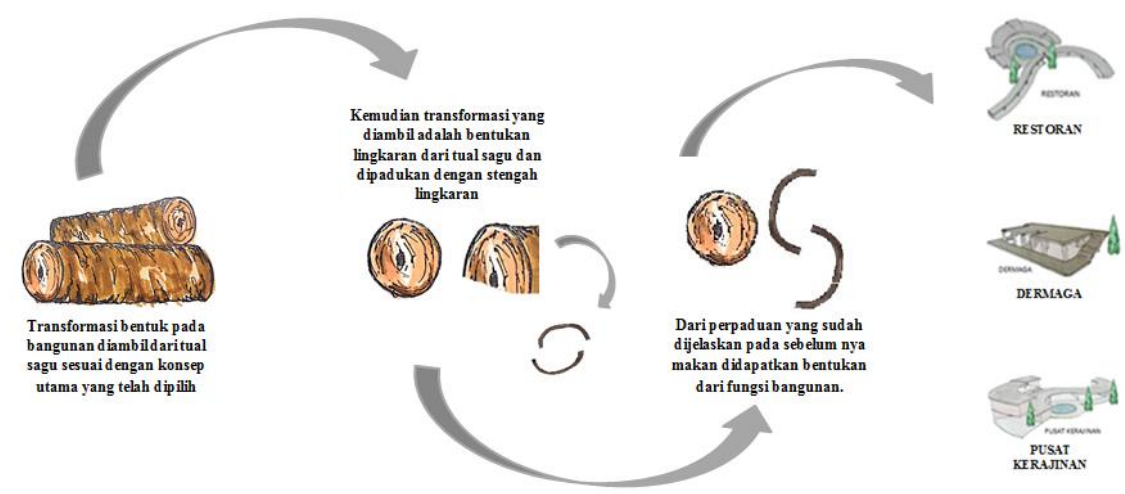

Gambar 28. Proses Transformasi Desain Fungsi Objek Perancangan Sumber: Data Pribadi, 2020
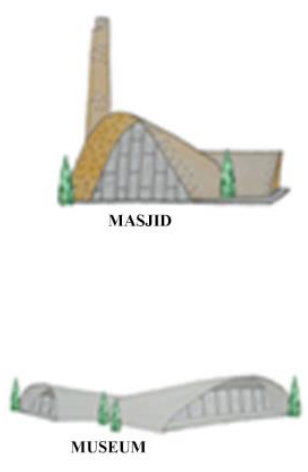

Gambar 29. Tampilan Beberapa Objek Perancangan
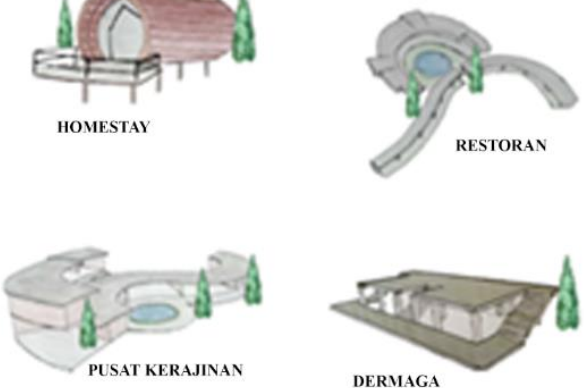

RESTORAN

Sumber: Data Pribadi, 2020

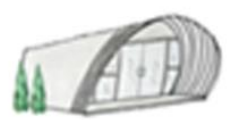

RETAIL

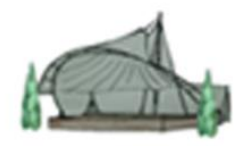

PANGGUNG

\subsubsection{Penerapan Perletakan Bangunan}

Penerapan konsep terhadap perletakan bangunan pada kawasan diambil dari ciri fisik tual sagu, yang dimana tual sagu memiliki beberapa lapisan mulai dari kulit sagu, serat sagu, hingga isi sagu yang dimana bisa di olah menjadi makanan. Dan disini penerapan yang di ambil pada perletakan bangunan adalah dari lapisan sagu yang sudah dijelaskan pada sebelumnya.

Mulai dari kulit sagu yaitu (fungsi pendukung), pada serat sagu yaitu (fungsi penunjang), dan pada isi sagu yaitu (fungsi utama) Hal ini bertujuan agar kawasan terlihat lebih tertata dan bisa lebih dinikmati oleh wisatawan yang berkunjung. Dan penerapan perletakan bangunan dapat dilihat pada gambar 21:
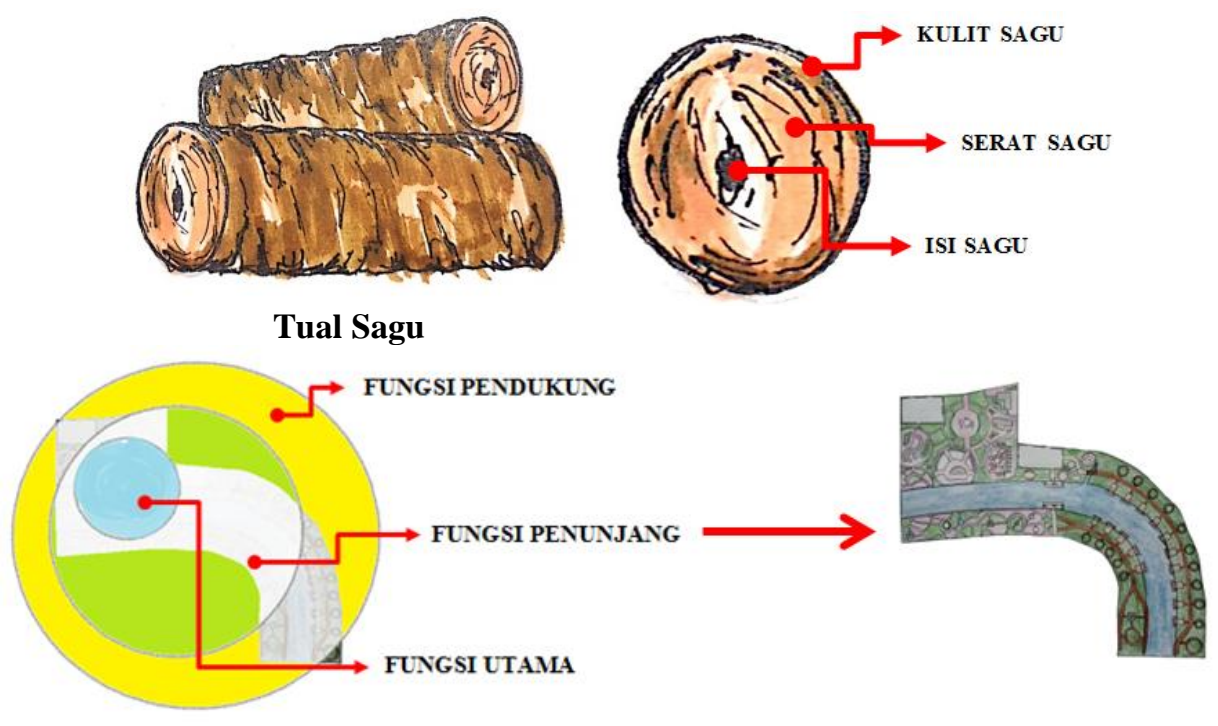

Gambar 30. Penerapan Perletakan Bangunan Sumber: Data Pribadi, 2020 


\section{Kesimpulan}

Perancangan Perancangan Kawasan Wisata Desa Bokor Dengan Pendekatan Arsitektur Tepian Air diharapkan dapat memenuhi dan mewadahi kebutuhan masyarakat dan kegiatan wisatawan. Fasilitas yang terdapat pada perancangan ini yaitu berdasakan masyarakat mau pun wisatwan yang berkunjung, seniman, peminat, pemerhati kesenian maupun pengunjung yang hanya berekreasi. Kawasan Wisata Desa Bokor juga dilengkapi fasilitas pendukung diantaranya Play Ground, Pusat Industri Kerajinan, Dermaga, Restoran, Retail, Homestay, RTH, Panggung Terbuka, dan Masjid, lalu di kombinasikan dengan pendekatan Kawasan Tepian Air.

Suatu penataan Kawasan Wisata Desa Bokor sangat penting karena mampu mempengaruhi kwalitas dari aktivitas budaya, memberi nilai positif pada keberlansungan ekonomi dan pelestarian budaya masyarakat menjadi lebih baik dari waktu ke waktu. Penataan kawasan ini menggunkan pendekatan Arsitektur Tepian Air.

Penerapan konsep perancangan Kawasan Wisata Desa Bokor ini merupakan karakteristik dimana Pemilihan konsep ini didasari dari pohon sagu, yang dimana pohon sagu adalah pohon endemik yang ada di Kabupaten Kepulauan Meranti. Proses pengembangan konsep dasar "Tual Sagu" guna mendapatkan bentukan menggunakan ciri arsitektur tepian air yaitu, kawasan yang berlokasi ditepian air, area pelabuhan, fungsi utama sebagai kawasan wisata, orientasi ke perairan, pembangunan yang kearah vertikal dan horizontal. Dari konsep dasar "Tual Sagu" ini kemudian dikembangkan lagi menjadi sebuah pola kawasan dengan membentuk pola melengkung pada kawasan guna dijadikan sebagai zona dari setiap fungsi yang ada pada kawasan.

\section{Ucapan Terima Kasih}

Ucapan terimakasih kepada Dosen Pembimbing yang telah mem-bimbing penulis sampai dengan detik ini, terima kasih kepada Ketua Jurusan Prodi Arsitektur Universitas Riau, dan terimakasih kepada seluruh pihak yang telah membantu penulis dalam menjalankan penulisan ini.

\section{Referensi}

Breen, A., \& Rigby, D. (1994). Waterfronts: Cities Reclaim Their Edge. Mc. Graw Hill.

Edi Sedyawati. 1998. Keragaman dan Silang Budaya. Jakarta: MSPI.

Emil Salim. 1993. Hubungan Pariwisata dengan Budaya di Indonesia: Prospek dan Masalahnya. Jakarta: Direktorat Sejarah dan Nilai Tradisi Proyek Penelitian Pengkajian dan Pembinaan nilai Budaya, Depdikbud.

DPRD Kabupaten Kepulauan Meranti, \& Bupati Kepulauan Meranti. (2012). Peraturan Daerah Kabupaten Kepulauan Meranti Tahun 2012 Tentang Rencana Tata Ruang Wilayah Kabupaten Kepulauan Meranti Tahun 2011-2031.

D.K.Ching, Francis. Arsitektur: Bentuk, Ruang dan Tatanan. Edisi Ketiga. Jakarta: Erlangga,2008.

Hanggoro, Bintang P. 2012. "Pengembangan Model Konservasi Kesenian Loka sebagai Kemasan Seni Wisata di Kabupaten Semarang". Harmonia (Online), Vol.12,No.2 : Hal.167. (https://journal.unnes.ac.id/nju/index.php/harmonia/article/view/2525/2578 Diakses 31/03/2019 20:59)

Lubis, M. I. (2018). Penataan Kawasan Di Dusun Nelayan Insit Kepulauan Meranti Dengan Pendekatan Arsitektur Tepian Air. Universitas Riau.

Meyers, K. (2009). Pengertian Pariwisata. Unesco Office.

Neufert, E. (1996). Data Arsitek Jilid I Terjemahan oleh Sunarto Tjahjadi. Erlangga.

Pemdes Desa Bokor. (2019). Potensi Wisata. http://bokor.desa.id/kategori/potensi/tempat-wisata/

Triatmodjo, Bambang, 2009. Perencanaan Pelabuhan, Beta Offset: Yogyakarta.

Tangkuman, Dwi Juwita dan Linda Tondobala,. 2011. Arsitektur Tepi Air (Waterfront Architecture) dalam Jurnal Media Matrasain Vol 8 No 2 Agustus 2011.

Yahya, M,. 2013. Rekayasa Lingkungan Pelabuhan Pendaratan Ikan (PPI) Di Pelabuhan Paotere Makassar, dalam jurnal Temu Ilmiah IPLBI 2013

Spillane, J. J. (1982). Pariwisata Indonesia, Sejarah dan Prospeknya. Kanisius. 